\author{
Marzena Chrost* \\ ORCID: 0000-0003-3309-6574 \\ Kraków, Polska
}

\title{
Refleksyjna samoświadomość i działanie osoby
}

\section{Reflective Self-Consciousness and Activity of a Person}

\begin{abstract}
A human being is a person who experiences himself and acts as a person, therefore, he/she is conscious of him-/herself and that he/she acts consciously and responsibly. He/she is the maker of his/her actions and also has the ability to manage his/her actions, which shows his/her subjectivity and this is related to the structure of the person. The aim of the article is to present and analyse the meaning and role of consciousness and self-consciousness in human psychosocial functioning and activity in the perspective of reflectivity. This problem is very complex and difficult to explain and describe clearly. Therefore, in the theoretical terms, I will display only selected aspects. First of all, I will present the concept and the essence of consciousness and self-consciousness of a person, paying attention to the typologisation and reflective form. Then, I will discuss one of the components of self-consciousness, which is the reflection, and show reflexivity as the core of postmodern human activity. In the pedagogical aspect, I will pay particular attention
\end{abstract}

* Dr Marzena Chrost, Instytut Nauk o Wychowaniu, Wydział Pedagogiczny, Akademia Ignatianum w Krakowie, e-mail: marzena.chrost@ignatianum.edu.pl. 
to shaping the need for reflectivity in the process of self-upbringing and discuss the selected techniques of work on own reflectiveness.

Keywords: activity; reflection; reflexivity; consciousness; self-consciousness.

Abstrakt: Człowiek jest osobą, która doświadcza siebie i działa jako osoba, jest zatem świadomy siebie, oraz tego, iż świadomie i odpowiedzialnie działa. Jest sprawcą swoich czynów i ma również możliwość kierowania swoim postępowaniem, co ukazuje jego podmiotowość i związane jest ze strukturą osoby. Celem artykułu jest przedstawienie i analiza znaczenia oraz roli świadomości i samoświadomości w psychospołecznym funkcjonowaniu i działaniu człowieka w perspektywie refleksyjności. Problem ten należy do zagadnień bardzo złożonych i trudnych do wyjaśnienia i jednoznacznego opisania. W związku z tym, w ujęciu teoretycznym omówię tylko wybrane aspekty. W pierwszej kolejności przedstawię pojęcie i istotę świadomości oraz samoświadomości osoby ze zwróceniem uwagi na typologizację i formę refleksyjną. Następnie omówię jeden z komponentów samoświadomości, jakim jest refleksja oraz ukażę refleksyjność jako istotę działania człowieka ponowoczesnego. W aspekcie pedagogicznym szczególnie zwrócę uwagę na kształtowanie potrzeby refleksyjności $\mathrm{w}$ procesie samowychowania i omówię wybrane techniki pracy nad własną refleksyjnością.

Słowa kluczowe: działanie; refleksja; refleksyjność; świadomość; samoświadomość.

\section{Wprowadzenie}

W perspektywie personalistycznej człowieka traktuje się jako byt osobowy, którego istotnymi cechami są podmiotowość, wolność, godność. Dlatego należy stwierdzić, że bardzo ważne jest

aby wszystkie poziomy życia i wszystkie władze, którymi człowiek posługuje się w swoim życiu, były tak usprawniane, by postępowanie człowieka stawało się coraz bardziej wolne i niezależne od zewnętrznych i wewnętrznych determinant i przybierało coraz bardziej cechę stałości, a więc było zgodne z naturą ludzką i ostatecznym celem ludzkiego życia (Mazur i in., 2019, s. 65).

Człowiek jest osobą, która doświadcza siebie i działa jako osoba, jest zatem świadomy siebie oraz tego, iź świadomie i odpowiedzialnie działa. Jest 
sprawcą swoich czynów i ma również możliwość kierowania swoim postępowaniem, co ukazuje jego podmiotowość i związane jest ze strukturą osoby.

Teoria osoby wskazuje niewątpliwie na wyjątkowość człowieka. Jakie jest źródło owej wyjątkowości? Teoria ta podkreśla, że tylko człowiek - w przeciwieństwie do innych żyjących bytów: roślin i zwierząt - jest istotą duchową i jako taki jest wolny (nie podlega determinizmom, którym podlegają rośliny i zwierzęta). Jego duchowość ujawnia się w jego działaniu. Człowiek jest podmiotem - jego działanie wynika $\mathrm{z}$ wnętrza; poszczególne czyny znajdują swoje źródło w jego wolnych decyzjach (Horowski, 2015, s. 28).

Człowiek nieustannie rozwija i kształtuje siebie jako osobę, proces ten dokonuje się przez całe życie. „Rozwój osobisty ma być oparty przede wszystkim na świadomym rozwijaniu własnej duchowości. To rozwój duchowości ma przynieść wzrost refleksyjności, a co za tym idzie, większe poczucie podmiotowości i sprawstwa, odnalezienia drogi do własnej tożsamości i głębszych więzi z innymi" (Olbrycht, 2018, s. 80). Osoba poznając siebie rozwija wiedzę o sobie. Dlatego bardzo istotne jest kształtowanie całego człowieka, integralne wychowanie, które jest dla człowieka zarówno dobrem, jak także zadaniem i wyzwaniem.

Obecnie zaobserwować można niepokojące tendencje związane $\mathrm{z}$ funkcjonalnym i użytecznym podejściem do człowieka i świata. „Postęp związany z rozwojem Internetu, elektroniki, mediów masowych, telefonów przenośnych i innych udogodnień umożliwia natychmiastowość, zmienia stosunek do czasu, tradycji, ale także przeżyć i doświadczeń relacji z innymi" (Lasocińska, 2011, s. 47). Teraz człowiek, szczególnie młody, musi mieć iPhona, klikać, postować, twitować i tiktokować.

Fakt, że „w świecie, pełnym głębokich zmian i modernizacji z udziałem wiedzy, refleksyjność staje się niezbędnym i koniecznym narzędziem nowej racjonalności myślenia i działania" (Dróżka, 2006, s. 31), jak również wyzwania, jakie przynosi współczesny świat w postaci: biotechnologii, neurotechnologii, cybernetyki czy też sztucznej inteligencji, stały się cenną inspiracją do ukazania szczególnego znaczenia oraz roli świadomości i samoświadomości w psychospołecznym funkcjonowaniu i działaniu człowieka. Niewątpliwie problem ten należy do zagadnień bardzo złożonych i trudnych do wyjaśnienia i jednoznacznego opisania. Niemniej ukazanie problematyki świadomości i samoświadomości osoby w aspekcie refleksyjności i działania wydaje się ważne. Dlatego w ujęciu teoretycznym omówię tylko wybrane aspekty. W pierwszej kolejności przedstawię pojęcie i istotę świadomości 
oraz samoświadomości osoby ze zwróceniem uwagi na typologizację i formę refleksyjną. Następnie omówię jeden z komponentów samoświadomości, jakim jest refleksja oraz ukażę refleksyjność jako istotę działania człowieka ponowoczesnego. W aspekcie pedagogicznym szczególnie zwrócę uwagę na kształtowanie potrzeby refleksyjności w procesie samowychowania i omówię wybrane techniki pracy nad własną refleksyjnością.

\section{Pojęcie i istota świadomości}

W literaturze przedmiotu przedstawianych jest wiele koncepcji świadomości, które są bardzo zróżnicowane w aspekcie filozoficznym, merytorycznym oraz metodologicznym. Nie ma jednego i spójnego podejścia do tego zagadnienia, dlatego też jest wiele pojęć, którymi określa się to zjawisko. Dodatkowo są one także utożsamiane albo powiązane z samoświadomością i często stosowane zamiennie. Można do nich zaliczyć między innymi takie terminy jak: samoświadomość (self-awareness, self-consciousness), autokoncentracja (self-focus, self-attention) czy autorefleksja (self-reflection). Świadomość nie jest czymś prostym i jednorodnym, posiada bowiem wiele różnych aspektów i poziomów.

Świadomość to „posiadane przez każdego odczucie własnego istnienia i swych czynów" (Didier, 1996, s. 388). Często utożsamiana jest z uwagą, z postrzeganiem, z funkcją czuwania, i określana jest jako:

bezpośrednia wiedza, jaką każdy z nas posiada o swym istnieniu, swych czynach oraz świecie zewnętrznym. Świadomość, organizując dane dostarczane jej przez zmysły i pamięć, sprawia, iż możemy się umiejscowić w czasie i w przestrzeni. Nie istnieje ona jako wydzielona funkcja, posiadająca określoną strukturę i „siedzibę” w mózgu. Nie jest ani czymś wewnętrznym, ani czymś zewnętrznym, to stosunek do percypowanego świata (Sillamy, 1995, s. 290).

Fenomen świadomości, zdaniem Stanisława Kowalczyka,

jest ekspresją psychicznej interpretacji osoby ludzkiej, będąc niejako posiadaniem siebie w tym, co przynależy człowiekowi w jego osobistym wewnętrznym „azylu”. Człowiek, jako istota refleksyjnie myśląca, nie ogląda siebie z zewnątrz ani nie uprzedmiotawia siebie. Na tym polega jej funkcja ontologiczna. Dzięki świadomości i samoświadomości człowiek jest osobą, tj. podmiotem zdolnym 
do autonomii: poznawczej, dążeniowej, aksjologicznej, społecznej (Kowalczyk, 2002, s. 72).

W aspekcie poznawczym: „Świadomość można nazwać poznaniem poznania czy wiedzą wiedzy. Przede wszystkim jest wiedzą, jaka towarzyszy wszelkiej aktywności psychicznej. To dzięki niej człowiek zdaje sobie sprawę z własnych przeżyć i działań” (Chrost S., 2020, s. 128).

Najbardziej specyficzną i dystynktywną cechą świadomości jest zdolność do samoujawniania się sobie, czyli zdolność do samoprzenikania, samoprzezroczystości. Dzięki niej przeżycia świadome kierują się nie tylko w stronę przedmiotów wobec nich transcendentnych, ale również w stronę samych siebie. Cechą świadomości jest także refleksywność, która umożliwia przeżycie siebie i swoich stanów jako należących do podmiotu, jakim jest nasze Ja.

Świadomość jest czynnikiem współkonstruującym jednostkę i pełni dwie zasadnicze funkcje. Pierwszą można określić mianem prześwietlająco-odzwierciedlającej, drugą zaś refleksywną. Dwie funkcje świadomości można utożsamiać z dwoma rodzajami refleksyjności, odpowiednio - refleksyjnością przedmiotową (dla funkcji prześwietlająco-odzwierciedlającej) i refleksyjnością podmiotową (dla funkcji refleksywnej) (Perkowska-Klejman, 2019, s. 82).

Świadomość człowieka stanowią trzy składniki: system posiadanych wiadomości; system wartości, ocen, poglądów i opinii; system posiadanych umiejętności i podejmowanych działań. Współdziałają one ze sobą i wzajemnie się przeplatają.

Wyróżnia się świadomość nierefleksyjną, która odnosi się do poznania jakiegoś przedmiotu oraz refleksyjną nakierowaną na samego człowieka. Świadomość refleksyjna jest cechą charakterystyczną osoby. Człowiek może i potrafi przeprowadzać refleksję nad samym sobą i swoimi czynami, działaniami, postępowaniem. Dzięki temu poznaje siebie, zdobywa wiedzę o sobie, zdobywa świadomość siebie, stąd może odpowiednio sobą pokierować. Dlatego człowiek ma świadomość siebie, swego człowieczeństwa, swojego istnienia, aktów.

\section{Samoświadomość osoby}

Dla osoby najbardziej podstawowa jest orientacja odnosząca się do własnego istnienia, dlatego pierwszym spostrzeżeniem powinno być istnienie 
wobec siebie; najpierw musi istnieć podmiot, aby mogło istnieć coś. Mechanizm samoświadomości polega na tym, że podmiot obiektywnie ogląda samego siebie, czyli można to określić jako „widzenie siebie przez siebie”.

Samoświadomość można zdefiniować jako mechanizm poznawczy, dzięki któremu osoba zapoznaje się ze swoimi własnymi aktualnymi i świadomymi przeżyciami. Należy zauważyć, że już przedrostek „samo-” wskazuje na przedmiot odniesienia. Jest nim własna świadomość, bezpośrednia świadomość siebie, czyli świadomość świadomości. Treści samoświadomości można rozróżnić na zewnętrzne i wewnętrzne (Zaborowski, 1998, s. 17). Aspekt zewnętrzny odwołuje się do informacji bardziej obiektywnych mających swoje źródło w kontaktach człowieka ze światem zewnętrznym i to zarówno w sferze kontaktów interpersonalnych, jak i szeroko pojętej ludzkiej działalności. Odnosi się zatem do rozmaitych relacji interpersonalnych i społecznych typu: Ja - inni. A to zmierza między innymi do kształtowania postawy człowieka, uwzględniającej rozmaitość relacji: Ja - inny, Ja - inni, Ja - świat. Kojarzy się on najczęściej z uczuciami nadziei, optymizmu, zaufania i innymi pozytywnymi emocjami. Natomiast aspekt wewnętrzny dotyczy sensu życia danej osoby, jej tożsamości oraz stylu życia. Często kojarzy się z uczuciami izolacji, samotności, smutku i zwątpienia, gdyż jej źródłem są bardzo subiektywne informacje o swoim Ja odniesionym do świata, innych ludzi i wzajemnych między nimi stosunków.

W ujęciu filozoficznym wyróżnione zostały dwa podstawowe rodzaje samoświadomości: przedrefleksyjna i refleksyjna. Samoświadomość przedrefleksyjna ma bardzo wiele nazw, między innymi: intuicja przeżywania (Ingarden, 1971, s. 377), praświadomość (Husserl, 1989, s. 182), samoświadomość preintrospekcyjna (Shoemaker, 1994, s. 395), świadomość wtórna (Brentano, 1999, s. 225), świadomość towarzysząca (Stępień, 1999, s. 137; Poczobut, 2008, s. 10). Przedrefleksyjna samoświadomość została opisana przez fenomenologów jako świadomość przeżywania w trakcie spełniania przeżycia świadomego, konstytutywny moment każdego świadomego przeżycia (por. Ingarden, 1971, s. 376). Obie formy samoświadomości są ze sobą splecione.

Integracyjno-holistyczne podejście do zagadnienia samoświadomości przedstawia teoria zaproponowana przez Zbigniewa Zaborowskiego, który stwierdził, że „Samoświadomość polega na kodowaniu, przetwarzaniu i integrowaniu informacji o własnej osobie" (Zaborowski, 2000, s. 95). Biorąc pod uwagę kryterium podziału, jakim jest miara zróżnicowania w sposobie przetwarzania treści o własnej osobie, wyróżnił on cztery formy samoświa- 
domości: osobową, obronną, zewnętrzną oraz refleksyjną (por. tamże, 2000, s. 53). Pojawiają się one kolejno w życiu człowieka.

Samoświadomość osobowa (indywidualna) polega na kodowaniu i przetwarzaniu informacji o własnej osobie odnoszących się najczęściej do celów, planów, problemów i wyzwań osobistych, których podstawą są: pamięć, wyobraźnia, przyzwyczajenia oraz schematy osoby. Ta forma jest najbardziej egocentryczna, cechuje ją osobiste i emocjonalne traktowanie treści. Oparta jest na podmiotowości, czyli silnej świadomości siebie, która może być wynikiem większej wiedzy, ale również siłowego trzymania się ego i własnej racji. Sprzyja umacnianiu i integracji struktury Ja (por. tamże, s. 53). Z kolei samoświadomość obronna (awersyjna) związana jest z negatywnymi emocjami: lękiem, niepokojem, zagrożeniem, stratą, niesprawiedliwością, stresem. To prowadzi do zniekształcania treści samoświadomości, dlatego też cechuje się zawężeniem postrzegania do postawy obronnej i zachowawczej, zmniejszeniem otwartości na nowe informacje, akceptowaniem tylko siebie, umożliwia utrzymanie oraz ochronę Ja (por. Zaborowski, 1998, s. 52). Natomiast samoświadomość zewnętrzna przyjmuje postać zobiektywizowanego i uspołecznionego przetwarzania informacji o sobie; sprzyja przystosowaniu społecznemu oraz zgodności zachowania z posiadanymi normami, wartościami. Odnosi się do uwewnętrznionych wartości, norm, standardów, wzorców osobowych. Forma refleksyjna funkcjonuje na podłożu pojęć i sądów ogólnych, które odnoszą się do informacji przetwarzanych przez pozostałe formy samoświadomości; pogłębia i obiektywizuje samowiedzę, stanowi również podstawę rozwoju tożsamości. Uznawana jest za najwyższą formę samoświadomości, ponieważ sprzyja dojrzałości społecznej, moralnej, samorealizacji, samookreśleniu, efektywnej regulacji i kontroli zachowania, jak również sprawiedliwości wewnętrznej polegającej na uczciwym, trafnym stosunku do własnej osoby. $Z$ jednej strony pozawala na utrzymanie konstruktywnej tożsamości, z drugiej zaś na generowanie progresywnych zmian w osobowości (por. Zaborowski, 2000). Warto zauważyć, że sprzyja samoregulacji zachowania i samokontroli dzięki dystansowaniu się, czyli zatrzymaniu reakcji, co pozwala na ponowne przemyślenie swojego przekonania, poglądu, zdobytego doświadczenia. Istotne jest stwierdzenie, że rozdzielenie etapu otrzymania informacji od własnej reakcji staje się możliwe za pośrednictwem refleksji. Omówione cztery formy samoświadomości można potraktować jako system czterech ruchomych filtrów, które mają różne parametry, mogą niektóre treści redukować, a inne dopełniać (por. tamże). 
Należy zauważyć, iż samoświadomość osoby można rozpatrywać w dwóch aspektach: statycznym i dynamicznym. Ujęcie statyczne odnosi się do aktualnego tu i teraz stanu wglądu w siebie, natomiast dynamiczne - do procesu rozwoju, dojrzewania i stawania się, który dokonuje się poprzez własny wysiłek w toku całego życia danej osoby. Niewątpliwie samoświadomość jest procesem bardzo złożonym, o różnym stopniu intensywności i wyrazistości. Można w niej wyodrębnić określone treści i formy, które z kolei mogą tworzyć specyficzne układy: Ja indywidualne, Ja obronne, Ja zewnętrzne i Ja refleksyjne. Taki system można określić mianem Ja podstawowego.

Jedną z podstawowych funkcji samoświadomości jest więc samopoznanie. Poczucie własnej wartości, wewnętrznej treści, spójności czy ciągłości to rezultaty przebiegających na podłożu samoświadomości procesów gromadzenia, przetwarzania i integrowania treści na swój temat (por. Zaborowski, 2001). Proces samopoznania jest warunkiem rozwoju oraz indywidualności każdego człowieka. Wymaga to szczególnej zdolności poznawania siebie samego, zwracania uwagi na otaczającą rzeczywistość oraz szczególnej wrażliwości. Dlatego bardzo ważne jest samopoznanie oraz dostrzeżenie w sobie samym osoby, która ma coś do darowania innym. „Funkcje samoświadomości łączą się ze zdobywaniem autoorientacji, samowiedzy, utrzymaniem i obroną tożsamości, przystosowaniem zewnętrznym i społecznym oraz z regulacją i sterowaniem zachowaniem celowym" (Zaborowski, 2000, s. 95). Ważnym składnikiem samoświadomości jest także samoakceptacja. Bycie świadomym siebie związane jest z procesem autokoncentracji, gdzie osoba jest podmiotem i jednocześnie przedmiotem swojej percepcji i poznania. Kiedy człowiek koncentruje uwagę na sobie samym, to zaczyna oceniać własne zachowanie i porównuje je ze swymi wewnętrznymi normami i wartościami.

Należy również zwrócić uwagę na pewien paradoks samoświadomości. $\mathrm{Z}$ jednej strony, daje ona wiele korzyści i pozytywnych skutków, natomiast z drugiej strony „wyniki badań wskazują, że bycie świadomym siebie nie tylko jest doświadczeniem nieprzyjemnym, ale też okazuje się wyróżnikiem wielu stanów psychopatologicznych" (Pilarska, 2010, s. 184).

Podsumowując, warto podkreślić, że samoświadomość jest to zdolność do dokonania rozróżnienia między sobą a fizycznym i społecznym otoczeniem oraz do stawania się przedmiotem własnej uwagi (por. Zaborowski, 2001). Osoba najpierw obiektywnie ogląda samą siebie, następnie na bazie właśnie tego oglądania ubiera swoje emocje, sądy, opinie w jakąś formę. Dopiero w następstwie tego postrzegania siebie staje się konkretna. Człowiek posiada bogate informacje o własnej osobie, pamięta również wiele faktów 
ze swojego życia, ma także rożne wspomnienia i wyobrażenia, uogólnia swoje zachowania i przeżycia, zdobywa pogłębioną samowiedzę i przejawia samoocenę. Ta samoświadomość człowieka „ma się odzwierciedlać w refleksyjnym wglądzie we własne wnętrze. Ten ważny element procesu samowychowania ma prowadzić do samopoznania" (Tchorzewski, 2017, s. 194).

\section{Refleksja jako komponent samoświadomości}

Samoświadomość integruje osobowość jednostki, jej zachowanie i środowisko w złożonych wzajemnych relacjach. W konstruowaniu świadomości i samoświadomości człowieka refleksja jest bardzo ważna. W literaturze przedmiotu czasami pojęcie samoświadomości używane jest zamiennie z pojęciem refleksji, ale niekiedy zdarza się, że pojęcie refleksji odnosi się wyłącznie do aktowych odmian samoświadomości i określa się je jako samoświadomość refleksyjna oraz prerefleksyjna (nierefleksyjna).

W związku z tym, warto ukazać różnicę między refleksją a świadomością (i samoświadomością), którą można opisać następująco: „Strumień świadomości to niekontrolowane przez podmiot myślenie, które nieustannie przebiega w umyśle i które, w przeciwieństwie do refleksji, jest przypadkowe i nieuporządkowane" (Białecka-Pikul, 2012, s. 289). Można z tego wywnioskować, że refleksja jest intencjonalna, a jej tok uporządkowany.

Termin ,refleksja” pochodzi od łacińskiego słowa reflexio oznaczającego „zginanie, przechylanie, odbijanie, zawracanie” (Kopaliński, 1989, s. 433). Definiowana jest jako „czynność umysłu polegająca na ujmowaniu lub tylko uświadamianiu własnych aktów (w tym samej refleksji) w aspekcie ich istnienia, zawartości, struktury i przebiegu" (Chudy, 2006, s. 68). Refleksja jest „podstawową cechą świadomości” (tamże, s. 68-69), świadomym procesem myślowym przejawiającym się w słowach ,ja myślę”, które są częścią zasady filozofii Kartezjusza - myślę, więc jestem (por. tamże, s. 69).

W tradycji klasycznej refleksja ma dwa znaczenia: ontyczne i poznawcze, obydwa typy są ważne dla tworzenia osobowego poziomu życia. W ujęciu ontycznym intelekt pojmuje własne pojmowanie, wola chce chcieć, a wola i intelekt przenikają się wzajemnie, człowiek żyje i działa jako osoba.

Refleksja charakteryzowana jest jako intencjonalny proces myślowy, który stanowi podstawową cechę świadomości. W tym aspekcie można wyróżnić dwa rodzaje refleksji: aktową i nieaktową. Refleksja aktowa ma bardzo szerokie spektrum, związana jest z metaprzedmiotowym i metateoretycznym wymiarem filozofii „od pola introspekcji psychologicznej, przez teoriopo- 
znawcze, fenomenologiczne lub transcendentalne śledzenie aktów świadomości, aż po system metanauki" (tamże, s. 68).

W wymiarze jedności osoby ludzkiej refleksja nieaktowa (towarzysząca lub przeżywaniowa) odgrywa ważną rolę, ponieważ „stanowi ważny współczynnik doświadczenia przez człowieka «na bieżąco» siebie jako całościowej integralnej jedności w toku jego życia osobowego" (tamże, s. 68). Jest szczególnie ważna, bo pozwala odsłonić swoje wnętrze sukcesywnie. Człowiek przekonuje się o własnej indywidualności osobowej, racjonalności, a także o własnej niepowtarzalności i wolności. Jest to doświadczenie „o charakterze przeżywaniowym (samoodsłaniającym się) i towarzyszącym” (tamże, s. 69) w trakcie własnego działania.

Ważne jest także ukazanie funkcji, jakie pełni refleksja. Do podstawowych można zaliczyć między innymi następujące: percepcyjną - refleksja pozwala dostrzegać nowe fakty bądź opracowywać dotychczasowe w odmienny sposób; deskryptywną - refleksja pozwala opisywać zdarzenia/fakty czy stan wiedzy; eksplanacyjną - refleksja umożliwia wyjaśnianie zdarzeń/ /faktów czy stanu wiedzy; predyktywną - refleksja pozwala przewidywać kolejne zdarzenia bądź zachowania oraz kierunki rozwoju wiedzy; heurystyczną - refleksja umożliwia stawianie pytań i wysuwanie hipotez dotyczących życia społecznego bądź stanu wiedzy; metapoznawczą - refleksja pozwala kontrolować źródła i nabywanie wiedzy oraz zachowywać krytyczny stosunek do własnej wiedzy; samopoznawczą - refleksja nad własnymi przekonaniami, przyzwyczajeniami czy zachowaniem sprzyja gromadzeniu wiedzy o sobie (por. Białecka-Pikul, 2012, s. 284-285).

Zdaniem Wojciecha Chudego: „Najważniejsza funkcja refleksji, zarówno w aspekcie filozoficznym, teologicznym, jak i pedagogicznym, polega na konstruowaniu i «przechowywaniu» w świadomości człowieka jego poczucia bycia sobą, którą konstytuują elementy rozumności i indywidualności" (Chudy, 2006, s. 71).

Podsumowując należy podkreślić, że refleksja jest bardzo ważnym i koniecznym konstruktem samoświadomości osoby. Niemniej należy także zauważyć, iż ponowoczesnemu człowiekowi „towarzyszy niespotykany dotąd pośpiech spowodowany dynamicznym rozwojem nowych technologii, które zmieniają jego dotychczasowe codzienne funkcjonowanie, zmieniają jego orientację życiową, w której brakuje miejsca na refleksję dotyczącą sensu jego życia i bycia” (Tchorzewski, 2016, s. 177). 


\section{Refleksyjność jako istota działania człowieka ponowoczesnego}

Pojęcie refleksyjności ma złożony i bardzo szeroki zakres, występuje w dyskursie filozoficznym, antropologicznym, socjologicznym, psychologicznym, prawniczym, pedagogicznym. Refleksyjność określana jest jako ogólna cecha człowieka, która prowadzi do samoświadomości i podmiotowości. Jest również kategorią, która ma swoje odniesienia do wielu różnych aspektów ludzkiej aktywności i działania. „Być świadomym to działać, wiedząc o tym, co się robi” (Chrost S., 2020, s. 128).

Postawa refleksyjna jest pożądaną i właściwą dyrektywą sprawnego i rozumnego działania człowieka. Dzięki refleksywności, która jest cechą świadomości, czyn staje się rzeczywistością podmiotową w człowieku. Refleksywność prowadzi osobę do doznawania siebie jako sprawcy czynu, do przeżywania wartości moralnej czynu. Określenia tego, czy jest on moralnie dobry, czy zły. Przeżywanie czynów może być zakłócone przez emocjonalizację świadomości, co jest następstwem tego, że człowiek przeżywając samego siebie, przeżywa także swoje ciało, które odbija się w świadomości. W tej sytuacji ważną rolę odgrywa samowiedza, która obiektywizuje emocje, uczucia oraz pozwala nad nimi zapanować. Dostrzegając i analizując swoje działania, człowiek natrafia na wolność, która wyraża się w doświadczeniu ,chcę lub nie chcę”, „muszę - mogę”; jest to właściwość samoopanowania siebie, które oznacza spełnienie władzy wobec siebie. Aby człowiek mógł sobie panować, powinien siebie posiadać. Samoposiadanie oraz samoopanowanie pozwalają z kolei na samostanowienie, co umożliwia człowiekowi kierowanie własnym postępowaniem (por. Kukołowicz, 1997, s. 68-69; Rynio, 2019, s. 495).

Interesujące ujęcie refleksyjności w ujęciu socjologicznym zostało ukazane przez Margaret S. Archer, która stwierdziła, że jest ona „regularnym doświadczaniem umysłowej zdolności, podzielanej przez wszystkich normalnych ludzi, do ujmowania siebie w relacji do swoich (społecznych) kontekstów i vice-versa" (Archer, 2007, s. 4). Czyni ją zatem istotą ludzkiego działania. W przedstawionej przez nią koncepcji refleksyjność jest właściwością działających podmiotów, ma status ontologiczny. Pozwala wyjaśnić, dlaczego ludzie w ogóle podejmują działanie, co ich motywuje do działania, jak również na określenie wpływu sytuacji społecznych na działanie oraz zakresu pośredniczenia refleksji w tym wpływie. To zakłada istnienie zewnętrz- 
nego wpływu, jak i subiektywnej odpowiedzi na ten wpływ. Niewątpliwie uwidacznia się to w konstruowaniu projektów działań, u podstaw których leży refleksyjność oparta na wewnętrznej konwersacji. Biorąc pod uwagę fakt, że nie jest możliwe życie w społeczeństwie bez projektów, można wywnioskować, że nie jest również możliwe bez refleksyjnego odniesienia.

Człowiek działa dzięki refleksyjności i na drodze wewnętrznej konwersacji przepracowuje swoje emocje, troski, postępowanie, które następnie mogą ulegać modyfikacji w czasie.

Kluczem do refleksji jest wybór odpowiedniej perspektywy analizy własnych doświadczeń i działań. W związku z tym można wyróżnić rodzaje refleksji związane z działaniem, którego dana refleksja dotyczy, a dokładniej z określeniem momentu jej dokonywania w stosunku do czasu działania. Dlatego biorąc pod uwagę to, czy namysł miał miejsce zanim działanie się rozpoczęło, czy w trakcie działania, czy już po, można wyróżnić trzy rodzaje refleksji: przed działaniem, w trakcie i po działaniu (Chrost M., 2018a, s. 39).

Należy także podkreślić, że człowiek nie tylko poznaje siebie i swoje działanie, ale potrafi je również ocenić, wartościować pod względem moralnym. Poznaje zgodność działań z zasadami moralnymi, posiada zatem świadomość swoich aktów, czynów, czemu towarzyszy świadomość nagrody albo winy. Zagadnienie to odnosi się do świadomości moralnej, a w sposób szczególny do fenomenu sumienia. Jest to problematyka bardzo złożona, która niewątpliwie wymaga szerszego, szczegółowego i oddzielnego omówienia.

Refleksyjność daje człowiekowi również możliwość formułowania ważnych pytań:

jaki powinienem być i w jaki sposób powinienem postępować, by z jednej strony dochować wierności sobie i nie ulec duchowemu zniewoleniu, a z drugiej - by swoim postępowaniem nie ograniczać innych ludzi w ich prawach do wewnętrznej wolności i podmiotowości i w prawie do wyboru własnej drogi? (Kwaśnica, 2004, s. 300).

Pytania te są bardzo ważne szczególnie dla dzisiejszego człowieka. Dlatego istotne jest zwrócenie uwagi, aby osoba była zdolna do podejmowania głębokiej refleksji przy ocenie czynu etycznego, znała swoje powinności etyczne, potrafiła negocjować normy moralne, czuła się odpowiedzialna za swoje czyny i działała skutecznie dla dobra innych, potrafiła także dostrzegać perspektywę innego człowieka, nie wycofywała się w sytuacji, która wymaga 
odwagi w realizacji dobra. Ważne jest zatem wspieranie osoby w nabywaniu świadomości i samoświadomości oraz formacji sumienia.

W społeczeństwie konsumpcyjnym, pluralistycznym, absolutyzującym rozum, pracę i sukces, człowiek chce być na bieżąco, na czasie. Dlatego nieustanie goni za tak zwanymi nowinkami, skupia uwagę na pojedynczych stwierdzeniach. Otrzymuje dużą ilość gotowych informacji, co powoduje, że niestety nie doszukuje się w nich prawdy i sensu. Sytuacja taka nie skłania go do namysłu, zastanawiania się, analizy czy też rozważania danych faktów i zagadnień, ale również nie prowadzi do autoanalizy. Niewątpliwie, do człowieka docierają informacje, które modelują jego sposób myślenia, decydowania i działania. Dlatego też z niepokojem można stwierdzić, że obecnie człowiek poddawany jest bardziej informatyzacji niż komunikacji (por. Chrost M., 2018b, s. 61).

Cechą osoby jest spojrzenie $\mathrm{z}$ dystansu na własne cele, działania, oraz stała czujność świadomości. $Z$ jednej strony refleksyjność motywuje człowieka do konkretnego działania i zmiany postępowania, natomiast $\mathrm{z}$ drugiej strony może być „niebezpieczna, jeśli utrudnia lub uniemożliwia działanie, odbiera siłę, unieruchamia, obezwładnia człowieka (melancholia)" (Starnawski, 2017, s. 85).

Warto zauważyć, że ponowoczesność wymaga od człowieka refleksyjności określanej jako

rodzaj kompetencji, zdolności i umiejętności myślowego zaprogramowania własnych relacji z otoczeniem - poprzez ciągłe, nieustanne monitorowanie (samoobserwację) swych intencji, motywów i powodów, a więc dążenie do krytycznego rozumienia źródeł swych celów, dążeń i zamierzeń, a także swego położenia w środowisku, swych możliwości oraz ograniczeń strukturalnych i podmiotowych (Dróżka, 2017, s. 147).

Podsumowując, należy stwierdzić, że refleksyjność sprzyja pogłębionemu zastanawianiu się nad sprawami podstawowymi, takimi jak pytania o to, co istnieje, jak istnieje, czy też po co istnieje. Obok pytań metafizycznych, człowiek refleksyjny stawia sobie również wiele pytań etycznych między innymi o normy, jakimi powinien się kierować w swoim postępowaniu. Refleksyjnośc pozwala również na rozumienie danej sytuacji i korzystanie z informacji zwrotnych w celu zmiany czy też modyfikacji swojego zachowania oraz działania. Skłania do rozważnego, roztropnego, efektywnego działania. Tak rozumiana refleksyjność jest bardzo ważną, przydatną, oraz niezbędną i konieczną kompetencją człowieka ponowoczesnego. 


\section{Kształtowanie potrzeby refleksyjności w procesie samowychowania}

Samowychowanie jest procesem złożonym i „towarzyszy procesowi wychowania wówczas, gdy wychowanek osiąga pewną dojrzałość i sam potrafi pokierować swoim rozwojem" (Tchorzewski, 2017, s. 204). Proces ten inicjowany i kierowany jest zatem przez osobę, która pełni w nim zarówno rolę wychowawcy, jak również wychowanka.

W procesie wychowania i samowychowania niezwykle ważne jest kształtowanie potrzeby refleksyjności. Potrzeba oznacza poczucie niespełnienia, braku czegoś, co jest potrzebne do życia, odpowiedniego funkcjonowania, zachowania gatunku czy też odpowiedniej roli społecznej. Zaspokojenie danej potrzeby jest podstawowym czynnikiem motywującym, który skłania osobę do działania, natomiast źródłem potrzeb są: fizyczna struktura organizmu człowieka oraz jego doświadczenia, a w sposób szczególny jego kontakty z otoczeniem społecznym. Pomimo różnorodności definicji i klasyfikacji potrzeb, które przedstawiane są w literaturze przedmiotu, należy zgodzić się z twierdzeniem, iż potrzeba jest czynnikiem, który jest źródłem aktywności człowieka i dynamizuje jego zachowanie. W związku z tym wydaje się, że potrzeba refleksji jest istotnym i koniecznym elementem, który powinien być uwzględniany i kształtowany w procesie rozwoju człowieka. Trzeba zauważyć, że

refleksja prowadzi do dostrzeżenia i eliminacji własnych błędów, niepowodzeń, modyfikacji własnych działań, bowiem stały rozwój i doskonalenie zapewni tylko racjonalna autoanaliza i autoobserwacja, które są fundamentem autonomii człowieka. Należy zatem stwierdzić, że autorefleksyjność to praca, własny wysiłek rozumienia siebie, własnych postaw i działań, które należy stale analizować, oceniać i modyfikować. $Z$ autorefleksją ściśle związane są takie pojęcia jak: samoocena, samoobserwacja, samowiedza czy samopoznanie (Chrost M., 2017, s. 141).

Niewątpliwie refleksja i autorefleksja są czynnikami, które umożliwiają i doskonalą proces samowychowania. Związane są również z dowartościowywaniem autonomii osobowej, jak i kreatywności człowieka, co stanowi istotne fundamenty współczesnego wychowania. Dlatego też, w aspekcie pedagogicznym, warto zastanowić się nad tym, co pomaga w kształtowaniu potrzeby refleksyjności w procesie samowychowania. Niewątpliwie, reflek- 
syjność można rozwijać poprzez ćwiczenia i systematyczną pracę nad sobą. W literaturze przedmiotu przedstawiane są różne opisy konkretnych technik pracy nad własną refleksyjnością, które w większości omawiane są szczególnie w odniesieniu do pracy nauczyciela. Niemniej, myślę, że mogą one z powodzeniem być stosowane i wykorzystane przez każdego, kto chce rozwijać swoją refleksyjność. Z uwagi na różnorodność i wielość tych technik omówię tylko niektóre z nich. Do wybranych sposobów, które mogą pomagać osobie w nabywaniu nawyku dokonywania refleksji, można zaliczyć między innymi: prowadzenie dzienników refleksyjnych, podejmowanie dialogu z samym sobą, prowadzenie refleksyjnego portfolio.

Jedną z podstawowych i ogólnie dostępnych technik rozwijania refleksyjności jest prowadzenie dziennika. Ta pisemna refleksja nad sobą samym i swoim doświadczeniem jest praktycznym sposobem zaangażowania się w proces refleksji. Zapis myśli, które nasuwają się spontanicznie oraz rozważań prowadzonych $\mathrm{z}$ namysłem jest ważnym sposobem na utrwalenie wydarzeń, doświadczeń, do których można także w przyszłości powracać. W dzienniku można odnotowywać osobiste zapiski z obserwacji, odczuć, reakcji, jak również cytaty z przeczytanych publikacji czy też własne do nich komentarze. Jest wiele odmian tej metody, najprostszą formą są notatki zapisywane w kalendarzu, mogą to być również osobiste dzienniki czy też autobiografie. Mogą one być prowadzone w formie tradycyjnej (papierowej) lub elektronicznej. Z pewnością narzędzia te pozwalają na wyrażanie osobistego i dynamicznego wrażenia z własnego rozwoju, zachowania, działania i postępowania. Pozwalają na dokonywanie pogłębionej analizy danych sytuacji i swojej w nich roli, ukazują również sens doświadczanych przeżyć. Niewątpliwie stają się cennymi i ciekawymi narzędziami w procesie samopoznania i jednocześnie mogą być ważną inspiracją do podejmowania dalszych, pogłębionych refleksji. Zapisanie myśli i ich zwerbalizowanie pozwala stawiać kolejne pytania, cele, problemy do przemyślenia. Pisanie uwidacznia proces przejścia od zastanawiania się nad wybranymi aspektami do sformułowania konkluzji i podjęcia konkretnych decyzji (por. Jankowska, 2019, s. 61; Perkowska-Klejman, 2018, s. 20).

Rozwijanie potrzeby refleksyjności dokonuje się również poprzez formułowanie pytań do samego siebie, które inicjują wewnętrzny dialog. Pytania te mogą przybierać różnorodne formy, między innymi mogą to być pytania: opisowe, samooceniające, przyczynowe, decydujące. Pytania opisowe umożliwiają werbalizację własnych rozważań, przekonań, emocji oraz sposobów działania. Z kolei pytania samooceniające odnoszą się do oceny jakości rozważań, poglądów, stanowisk, sposobów postępowania, natomiast 
przyczynowe skierowane są na ujawnienie przyczyn i źródeł uświadomionych stanowisk, emocji, myślenia pedagogicznego, sposobów postępowania. Do zmiany nastawień, poglądów oraz sposobów działania prowadzą pytania decydujące. Podejmowanie dialogu z sobą może zapobiegać powstawaniu problemów, powodować ich dobre rozwiązania, jak również przeciwdziałać rutynie i schematyzmowi w działaniu (por. Jankowska, 2019, s. 61-62).

Portfolio wywodzi się z obszaru kultury i sztuki, w którym artyści dokumentują efekty swoich prac (np. zdjęcia, wytwory sztuki). Ogólnie można powiedzieć, że jest to bardzo osobista teczka, która zawiera dokumentację działalności i dokonań człowieka. Jest to technika monitorowania indywidualnego rozwoju osoby, która pozwala na ogląd kompetencji, umiejętności i możliwości. Zbierane, gromadzone i przechowywane materiały niewątpliwie sprzyjają uruchamianiu świadomej i pogłębionej refleksji nad samym sobą oraz nad działaniem. Osoba, dzięki systematycznie prowadzonemu portfolio, może także dokonać systematycznej autoewaluacji swojego rozwoju. Takie przyglądanie się konkretnym efektom swojej pracy (dyplomom, projektom, esejom) inspiruje również do udzielania sobie samemu odpowiedzi na podstawowe pytania, między innymi takie jak: co zgromadziłam?, co mam?, co z tego wynika?, jakie są moje cele?, do czego chcę jeszcze dążyć?, jak dalej mogę się rozwijać? Z pewnością jest to wyraz głębokiego myślenia o swoim uczeniu się, działaniach oraz ich efektach (por. Jankowska, 2019, s. 60-61; Perkowska-Klejman, 2018, s. 42).

Człowiek posiada dane zmysłowe, które pozwalają na poszerzanie wiedzy, a dzięki inteligentnemu i refleksyjnemu przetwarzaniu tych danych poszerza zakres samoświadomości, czyli wiedzy o sobie samym. Niemniej budowanie świadomości Ja potrzebuje do zaistnienia obecności drugiego człowieka. Dlatego też poznanie samego siebie powinno prowadzić do zrozumienia innej osoby. „Niestety zubożenie języka w kulturze współczesnej spowodowane zwłaszcza technologicznym przełomem związanym z Internetem i telefonią komórkową jest główną przyczyną swoistej zapaści komunikacyjnej w wymiarze intra- i interpersonalnym. Współcześni coraz częściej nie rozumieją samych siebie, a tym bardziej nie rozumieją Innych" (Sobecki, 2017, s. 87).

Podsumowując, należy zauważyć, że w aspekcie pedagogicznym bardzo ważna jest samoświadomość osoby, która polega na zdawaniu sobie sprawy z własnych emocji, myśli, potrzeb, możliwości, zdolności, ograniczeń oraz działań. Stawanie się człowiekiem refleksyjnym jest procesem o charakterze bardzo zindywidualizowanym, osobistym, czasami nawet bardzo intymnym. Osoba bowiem dotyka głębokich, ukrytych pokładów swojej umysłowości, 
uczuciowości, a także duchowości. Z kolei ten wewnętrzny wymiar refleksji otwiera perspektywę odmiennych, wielowymiarowych doznań w procesie poznawania samego siebie i innych. Niewątpliwie ważne i konieczne jest zatem kształtowanie potrzeby refleksyjności w procesie wychowania i samowychowania, bowiem przyczynia się to do tworzenia realnego obrazu samego siebie i innych oraz konstruowania spójnego obrazu rzeczywistości.

\section{Podsumowanie}

W dzisiejszym rozpędzonym świecie pełnym lęku, strachu, zagrożenia, niepokoju i niepewności sytuacja człowieka jest złożona i trudna. Można zaobserwować zagubienie człowieka odnoszące się do jego osoby, podmiotowości, wyjątkowości. Wydaje się również, że człowiek przeżywa rozterkę, nie widzi sensu swojego działania, nie rozumie tego, co robi i po co to robi. Z pewnością jest to konsekwencją ponowoczesnej mentalności, życia w dobie industrializacji, digitalizacji, w kulturze masowej i konsumpcyjnej, gdzie uznaje się prawo do najróżniejszych form wiedzy, modeli życia czy wzorców postępowania, oraz brakuje jednoznaczności stabilności i dystansu. Tym bardziej, że współczesna cywilizacja stara się narzucić człowiekowi wiele pozornych imperatywów, które uzasadniane są prawem rozwoju i postępu. Wydaje się także, że człowiek kontrolowany jest przez wzrastającą liczbę wszelkiego rodzaju przepisów prawnych, i to zarówno w życiu społecznym, jak również szkolnym. Natomiast relacje międzyludzkie zostały zastąpione bezosobowymi przepisami, a dodatkowo wynikająca z obecnej pandemicznej sytuacji izolacja społeczna doprowadza do ograniczenia kontaktów międzyosobowych. Niewątpliwie brak refleksji jest jedną z poważniejszych konsekwencji życia człowieka w chaosie, a dostrzegalna współcześnie bezrefleksyjność budzi niepokój dotyczący indywidualnego rozwoju osoby. Każdy człowiek jest odpowiedzialny za samego siebie, za kształtowanie siebie jako osoby, rozwijanie swojej osobowości i nikt w tym nie może go zastąpić. To on podejmuje decyzję, czy i w którym kierunku chce się rozwijać. Można zatem wyróżnić trzy możliwości: brak kierunku rozwoju, wybór prowadzący do rozwoju zmysłowego lub umysłowego, ale nie Bożego oraz prowadzący do życia wiecznego. Należy zaznaczyć, że jeżeli osoba nie dokona wyboru i nie podejmie pracy nad swoim rozwojem, to grozi jej degeneracja. W aspekcie personalizmu chrześcijańskiego tylko rozwój, który prowadzi człowieka do Boga, jest dobry (por. Gajda, 2006, s. 115). Dlatego ważne jest odkrywanie tajemnicy własnego bycia i życia, dbanie o jakość sie- 
bie i swojego życia oraz rozwijanie refleksyjności, ponieważ dopóki człowiek żyje, to powinno być jego odpowiedzialnością.

\section{Bibliografia}

Archer, M. S. (2007). Making our Way Through the World. Cambridge: Cambridge University Press.

Archer, M. S. (2013). Człowieczeństwo: problem sprawstwa. Tłum. A. Dziuban. Kraków: Zakład Wydawniczy Nomos.

Białecka-Pikul, M. (2012). Narodziny i rozwój refleksji nad myśleniem. Kraków: Wydawnictwo Uniwersytetu Jagiellońskiego.

Brentano, F. (1999). Psychologia z empirycznego punktu widzenia. Tłum. W. Galewicz. Warszawa: PWN.

Chrost, M. (2017). Refleksyjność w wychowaniu. Proces poznawania siebie. Studia Paedagogica Ignatiana, 2, 131-144. http://dx.doi.org/10.12775/SPI.2017.2.006

Chrost, M. (2018a). Refleksyjność komponentem mądrości praktycznej. W: I. Jazukiewicz, E. Rojewska (red.), Sprawności moralne jako przedmiot refleksji wychowawczej (s. 33-47). Szczecin: Wydawnictwo Naukowe Uniwersytetu Szczecińskiego.

Chrost, M. (2018b). Refleksyjność wyzwaniem współczesnego świata. Studia Paedagogica Ignatiana, 4, 55-66. http://dx.doi.org/10.12775/SPI.2018.4.003

Chrost, S. (2020). Antropologia pedagogiczna w perspektywie personalizmu teistycznego. Warszawa: Difin.

Chudy, W. (2006). Refleksja. W: T. Pilch (red.). Encyklopedia pedagogiczna XXI wieku, t. 5 (s. 68-72). Warszawa: Wydawnictwo Akademickie „Żak”.

Didier, J. (1996). Stownik filozofii. Tłum. K. Jarosz, Katowice: Książnica.

Dróżka, W. (2006). Kategorie analityczne w badaniach pedeutologicznych - w świetle założeń refleksyjnych nurtów poznawczych w naukach społecznych. Chowanna, 1 (26), 26-48.

Dróżka, W. (2017). Refleksyjność jako postawa wobec zmiany - na kanwie autobiografii, pamiętników, wypowiedzi osobistych nauczycieli z ostatniego ćwierćwiecza. W: I. Paszenda (red.). Codzienność jako wyzwanie edukacyjne, t. 2: Refleksyjność w codzienności edukacyjnej (s. 145-162). Wrocław: Instytut Pedagogiki Uniwersytetu Wrocławskiego.

Gajda, A. (2006). Osobowość a osobistość w świetle myśli o. Jacka Woronieckiego. W: M. Pietrzak (red.), Osoba i osobowość - czynniki je ksztattujace (s. 103-115). Łódź: Archidiecezjalne Wydawnictwo Łódzkie. 
Horowski, J. (2015). Zapoznane kwestie w teorii pedagogii osoby: cielesność, przygodność, przebaczenie. Forum Pedagogiczne, 2, 27-39.

Husserl, E. (1989). Wykłady z fenomenologii wewnętrznej świadomości czasu. Tłum. J. Sidorek. Warszawa: PWN.

Ingarden, R. (1971). O niebezpieczeństwie ,petitionis principii” w teorii poznania. W: tenże, U podstaw teorii poznania (s. 357-380). Warszawa: PWN.

Jankowska, A. (2019). Jak można stawać się refleksyjnym nauczycielem. Około Pedagogii, 1, s. 52-65.

Kopaliński, W. (1989). Słownik wyrazów obcych i zwrotów obcojęzycznych. Warszawa: Wiedza Powszechna.

Kowalczyk, S. (2002). Zarys filozofii człowieka. Sandomierz: Wydawnictwo Diecezjalne.

Kukołowicz, T. (1997). Wychowujący nauczyciel. W: T. Kukołowicz (red.), Teoria wychowania. Wybrane zagadnienia (s. 68-69). Stalowa Wola: Oficyna Wydawnicza Fundacji Uniwersyteckiej.

Kwaśnica, R. (2004). Wprowadzenie do myślenia o nauczycielu. W: Z. Kwieciński, B. Śliwerski (red.), Pedagogika. Podręcznik akademicki, t. 2 (s. 291-320). Warszawa: Wydawnictwo Naukowe PWN.

Lasocińska, K. (2011). Niecodzienna codzienność - globalizacja wyzwaniem do refleksyjnego konstruowania własnej biografii. Civitas Hominibus. Rocznik Filozoficzno-Społeczny, 6, 46-50.

Mazur, P. S., Kiereś, B., Skrzyniarz, R., Płazińska, A. (2019). Jacek Woroniecki. Kraków: Wydawnictwo Naukowe Akademii Ignatianum w Krakowie.

Olbrycht, K. (2018). Edukacyjne wymiary wspierania rozwoju duchowości człowieka. Edukacja Międzykulturowa, 2 (9), 79-89.

Perkowska-Klejman, A. (2018). Refleksyjność w kontekście uczenia się. Poszukiwanie pojęć, modeli i metod. Przegląd literatury przedmiotu. Warszawa.

Perkowska-Klejman, A. (2019). Poszukiwanie refleksyjności w edukacji. Studium teoretyczno-empiryczne. Warszawa: Wydawnictwo Akademii Pedagogiki Specjalnej.

Pilarska, A. (2010). Cechy samoświadomości a nasilenie symptomów depresji. Roczniki Psychologiczne, 13(2), 183-199.

Poczobut, R. (2008). Rodzaje samoświadomości. Analiza i Egzystencja, 7, 5-31.

Rynio, A. (2019). Wychowanie do odpowiedzialności. Studium teorii i praktyki pedagogiki integralnej. Lublin: Wydawnictwo KUL.

Shoemaker, S. (1994). Introspection. W: W. Guttenplan (red.). A Companion to the Philosophy of Mind (s. 395-400). Oxford: Blackwell.

Sillamy, N. (1995). Słownik psychologii. Tłum. K. Jarosz. Katowice: Książnica. 
Sobecki, M. (2017). Rola refleksyjności w kreowaniu tożsamości kulturowej - kontekst pedagogiczny. Studia Pedagogiczne, L, 81-89.

Starnawski, W. (2017). Refleksja w codzienności - perspektywa pedagogii osoby. W:

I. Paszenda (red.). Codzienność jako wyzwanie edukacyjne, t. 2: Refleksyjność w codzienności edukacyjnej (s. 74-86). Wrocław: Instytut Pedagogiki Uniwersytetu Wrocławskiego.

Stępień, A. (1999). Rodzaje bezpośredniego poznania. W: tenże, Studia i szkice filozoficzne (s. 126-158). Lublin: Redakcja Wydawnictw KUL.

Tchorzewski, A. M. de (2016). Wstęp do teorii wychowania. Kraków: Akademia Ignatianum w Krakowie i Wydawnictwo WAM.

Tchorzewski, A. M. de (2017). Samowychowanie drogą osobistego rozwoju człowieka. W: A. Walulik, J. Mółka (red.), Septuaginta pedagogiczno-katechetyczna. Księga jubileuszowa dedykowana Księdzu Profesorowi Zbigniewowi Markowi SJ w siedemdziesiąta rocznicę urodzin (s. 193-208). Kraków: Akademia Ignatianum w Krakowie.

Zaborowski, Z. (1998). Świadomość i samoświadomość człowieka. Warszawa: Eneteia Wydawnictwo Szkolenia.

Zaborowski, Z. (2000). Teoria treści i form samoświadomości. Warszawa: Wydawnictwo Akademickie Żak.

Zaborowski, Z. (2001). Problemy psychologii życia. Warszawa: Wydawnictwo Akademickie $\dot{Z}$ ak. 